\title{
Spatial patterns and seasonal variation of snowpack sulphate isotopes of the Prince of Wales Icefield, Ellesmere Island, Canada
}

\author{
Vivian WASIUTA, ${ }^{1 *}$ Ann-Lise NORMAN, ${ }^{2}$ Shawn MARSHALL ${ }^{1}$ \\ ${ }^{1}$ Department of Geography, University of Calgary, 2500 University Drive NW, Calgary, Alberta T2N 1N4, Canada \\ E-mail: vwasiuta@postoffice.sandybay.utas.edu.au \\ ${ }^{2}$ Department of Physics and Astronomy, University of Calgary, 2500 University Drive NW, Calgary, Alberta T2N 1N4, Canada
}

\begin{abstract}
Ion-chemistry and sulphate-isotope values for snow samples from the Prince of Wales Icefield, Ellesmere Island, Canada, show distinct seasonal trends and spatial patterns. Sixteen surface snow samples from two transects, and 30 samples from five depth profiles, representing fall 2003 to spring 2004 accumulation, have been analyzed. Surface snow samples show decreasing $\mathrm{SO}_{4}{ }^{2-}$ and $\mathrm{Na}^{+}$ concentrations along with decreasing $\delta^{34} \mathrm{~S}$ values with distance inland and increased elevation. These trends follow an expected pattern of decreasing sea-salt aerosol impact with greater vertical and horizontal distance from sea-water sources. Depth-profile total sulphate and non-sea-salt sulphate increase in concentration with height in the snowpack, and these results, combined with $\delta^{34} S$ values that are more positive in fall snow, are consistent with increased amounts of anthropogenic sulphate in surface spring snow. Sulphate apportionment was performed on surface snow assuming an isotopically light sulphate source (anthropogenic plus volcanic) mixed with isotopically heavier sulphate from dimethylsulphide (DMS) oxidation and sea water. Isotopically light sulphate in surface snow was apparent at all elevations at a reasonably uniform concentration. DMS sulphate, however, decreased exponentially with altitude, reflecting an ocean level source with oxidation occurring during transport and deposition. The significance to multi-year deposition studies is that sulphate from DMS oxidation may be related to sea-ice conditions in the region.
\end{abstract}

\section{INTRODUCTION}

High-latitude glaciers that accumulate solid precipitation year-round with minimal melting offer the possibility to reconstruct past atmospheric chemistry, air-pollution history and climate. Aerosols including sulphate are integrated into the snowpack as snowflake nuclei and by dry deposition. The sulphate ion is chemically inert under snowpack and glacier conditions, and its isotope ratios are preserved, enabling insight into atmospheric processes and changes over time.

There is major interest in the biogeochemical cycle of atmospheric sulphur in the context of global change. The cycle is complex, it has a significant role in radiative forcing, and aspects such as the role of biogenic emissions on the sulphur cycle are poorly understood. In the Arctic, sulphate derived from gases released to the atmosphere as a consequence of grazing and decay of ocean phytoplankton may be related to negative climatic feedbacks and to sea-ice extent. This was first proposed by Charlson and others (1987) as the CLAW hypothesis (named after the initials of the authors who first proposed the hypothesis) which suggests a negative feedback to global warming via dimethylsulphide (DMS) sulphate. Marine phytoplankton and algae release a sulphur compound, dimethylsulfonioproprionate or DMSP, during cell lysis. Enzymatic cleavage of DMSP releases a volatile sulphur compound DMS into the water column where it may be oxidized, consumed, or released to the atmosphere (Andreae, 1990). Only a few percent of the total DMS in the water column escapes to the air, where it can be oxidized on the surface of particles to form low-volatility

*Present address: Institute of Antarctic and Southern Ocean Studies, University of Tasmania, Private Bag 77, Hobart, Tasmania 7001, Australia. methanesulphonate (MSA) or undergo reactions in the gaseous phase to form sulphur dioxide and then sulphate. These fine aerosols scatter incident solar radiation back to space, in addition to affecting the prevalence and radiative properties of clouds (von Glasow and Crutzen, 2004). Current negative radiative forcing by both natural and anthropogenic sulphate is estimated to approach or exceed the magnitude of the positive forcing of greenhouse gases (Houghton and others, 2001). Increased temperatures in the Arctic and open leads and coincident decreases in sea-ice extent are expected to result in increased Arctic Ocean productivity if the CLAW hypothesis applies (Rigor and Wallace, 2004). Measurements to define DMS sulphate flux are valuable tools which can be used to help evaluate whether the CLAW hypothesis applies in the Arctic as it experiences rapid climate change.

The altitude at which aerosols form from DMS oxidation is an important consideration with respect to their impact on climate forcing. If the majority of non-sea-salt sulphate is formed and is present at lower altitudes, this has implications for atmospheric chemistry as well as cloud formation. Clouds formed at low altitudes could alter vertical temperature gradients and act as an effective barrier to outgoing infrared radiation, resulting in increased Arctic surface temperatures as compared to clouds formed higher in the troposphere. The purpose of this study is to further our understanding of snowpack sulphate changes with elevation and to quantify seasonal variation of sulphate isotopes on the Prince of Wales (POW) Icefield, Ellesmere Island, Canada. Since little work has been done to date with sulphate from high-Arctic snow, these data provide baseline information about sulphate sources in the Arctic. A significant proportion of aerosol sulphate in Arctic snow has a marine biogenic origin (Legrand, 1995, 1997), but this has 
been difficult to quantify. Sulphate stable isotopes have the potential to identify isotopically distinct source contributions to snowpack sulphate and to quantify more definitively the biogenic proportion of snowpack sulphate. Previous work using stable isotopes of sulphate to infer sources and oxidation processes includes Patris and others (2000, 2002), Alexander and others (2002, 2003, 2004), Savarino and others $(2003 \mathrm{a}, \mathrm{b})$ and Jonsell and others (2005). To our knowledge, this study is the first examination of sulphate sources using $\delta^{34} S$ in an Arctic snowpack.

If sulphate isotopes can help determine source apportionment, they offer a new tool, complementary to ion chemistry, for identifying the geographic origins of moisture and the seasonality of precipitation at a site. Seasonal and spatial variability in air mass and vapour provenance need to be understood in ice-core-based climate reconstructions. For instance, paleotemperature inferences based on ice-core $\delta^{18} \mathrm{O}$ and $\delta \mathrm{D}$ values (e.g. Koerner and Fisher, 1990; Grootes and others, 1993) are subject to uncertainties due to varying seasonality of precipitation and vapour source region (e.g. NorthGRIP members, 2004). Improved understanding of $\delta^{34} S$ variations will therefore refine ongoing ice-core studies in the Canadian high Arctic, including two high-resolution ice cores spanning the last several millennia that were acquired from the POW Icefield in spring 2005. Because of the sensitivity of $\delta^{34} \mathrm{~S}$ to marine biogenic sources, we hypothesize that $\delta^{34} S$ may serve as a proxy of regional open-water (hence, sea-ice) conditions. For snow samples and ice cores on the POW Icefield, this will reflect sea-ice conditions in Baffin Bay, the dominant source of moisture for the region (Koerner, 1979). If we are able to tie $\delta^{34} S$ to open-water conditions, $\delta^{34} S$ will offer a valuable new proxy for ice-corebased sea-ice reconstructions extending beyond the historical record. Results presented here offer preliminary insight into the controls and variability of $\delta^{34} \mathrm{~S}$, and its potential as a paleoenvironmental proxy in the Canadian high Arctic.

\section{Sulphate isotopes}

Isotope mass variation results in different reaction rates during physical, chemical and biological processes, producing isotope fractionation. Isotope ratios of compounds in nature deviate from average values often in predictable ways, providing information about the origin of compounds and their biogeochemical history. The ratio of the most abundant sulphur stable isotopes, ${ }^{34} \mathrm{~S}$ and ${ }^{32} \mathrm{~S}$, is used for sulphur isotopic analysis. Variations in isotope abundance ratios are very small and difficult to measure. To ensure consistency over time within a laboratory and to enable comparison between laboratories, isotope abundance is measured relative to an international standard reference: Vienna Cañon Diablo Troilite (V-CDT) is the standard used for sulphur.

$$
\delta^{34} S=\left(\frac{\left[{ }^{34} S /{ }^{32} S\right]_{\text {sample }}}{\left[{ }^{34} S /{ }^{32} S\right]_{\text {standard }}}-1\right) \times 10^{3}
$$

in parts per thousand (\%o).

\section{Sulphate sources to the high Arctic}

The isotope ratio of sulphate in Arctic snow represents all natural and anthropogenic sources. Major sulphate sources to the Arctic atmosphere include anthropogenic pollutants from long-range transport (with low positive $\delta^{34} S$ values), volcanic emissions which are expected to be characterized by low positive $\delta^{34} \mathrm{~S}$ values (Nielsen and others, 1991), and marine sources (sea-salt and marine biogenic) which have high positive $\delta^{34} S$ values (Calhoun and others, 1991). Interpretation is strengthened by using ion chemistry along with meteorological and glaciological data. Lithic sources are generally not considered a major contributor to soluble sulphate. However, there is the potential for influence from marine evaporates $\left(\delta^{34} \mathrm{~S}=+10\right.$ to $+35 \%$ ) which outcrop near the field site (Nielsen and others, 1991). Long-range transport of anthropogenic pollutants in the Arctic follows seasonal cycles that are influenced by solar radiation and synoptic air-mass motion (Sirois and Barrie, 1999). Arctic haze studies have shown pollution transport into the north is mainly from Eurasian sources and has a strong seasonal cycle (Sharma and others, 2004). Atmospheric concentrations of sulphate are 10-20 times higher from January to April (peaking in February-March) than in summer (Sirois and Barrie, 1999). At polar sunrise, substantive chemical changes occur in the Arctic atmospheric boundary layer as a result of photochemical reactions and heterogeneous reactions of gases with aerosols, snow in the atmosphere and snow on the ground. These include the oxidation of sulphur dioxide to sulphate (Toom-Sautry and Barrie, 2002). Little isotope selectivity is anticipated on oxidation under present atmospheric conditions, although this may not have been the case during glacial periods (Saltzman and others, 1983; Alexander and others, 2003; Norman and others, 2004). The proportion of anthropogenic sulphate (with $\delta^{34} \mathrm{~S}=+3$ to +7\%o) (Nriagu and others, 1991; McArdle and others, 1998; Norman and others, 1999; Patris and others, 2002) increases through the fall and winter to peak in spring snow.

Sea-salt $\left(\delta^{34} S_{S S}=+21 \%\right.$ ) and marine biogenic sulphate, which contribute significantly to the sulphate content of Arctic snow, also follow seasonal cycles. A conservative estimate of the marine biogenic contribution using $\delta^{34} \mathrm{~S}_{\mathrm{DMS}}=+19.5 \%$ is based on research of Patris and others (2000) $\left(\delta^{34} S_{\text {DMS }}=+18.6 \% \pm 0.9 \%\right.$ ). Biogenic compounds peak in the spring and summer, when northern oceans are highly productive (Li and others, 1993). Sea-salt aerosols peak in the late autumn and winter (Sirois and Barrie, 1999). The contribution to the Canadian Arctic by volcanic degassing is unknown (Newman and others, 1991). Although the range in $\delta^{34} \mathrm{~S}$ values for the anthropogenic and volcanic component could be quite large, long-term measurements of aerosol sulphate at Alert, Canada, during winter months can be used as a proxy. On average, $\delta^{34} \mathrm{~S}$ values for aerosol sulphate in winter do not vary by more than $\sim 1 \%$. (Nriagu and others, 1991; Li and others, 1993; Norman and others, 1999). Since anthropogenic and volcanic sulphur have similar $\delta^{34} \mathrm{~S}$ values and cannot be distinguished, the two are discussed together in this paper. A value of $\delta^{34} \mathrm{~S}_{\mathrm{A}}=+4.3 \%$ (anthropogenic plus volcanic) was selected based on aerosol sulphate at Alert for the 2003 winter months (Norman and others, unpublished information).

\section{SAMPLING}

The field site on the POW Icefield is located at approximately $79^{\circ} \mathrm{N}, 76^{\circ} \mathrm{W}$ in the Canadian high Arctic (Fig. 1). POW is a large icefield $\left(\sim 19000 \mathrm{~km}^{2}\right)$ with a maximum elevation of $2300 \mathrm{~m}$ a.s.I. On the east side of the icefield, valley glaciers descend to sea level between mountainous ridges. Broad lobate glaciers form the west edge of the icefield and terminate terrestrially at 400-600 ma.s.I. 


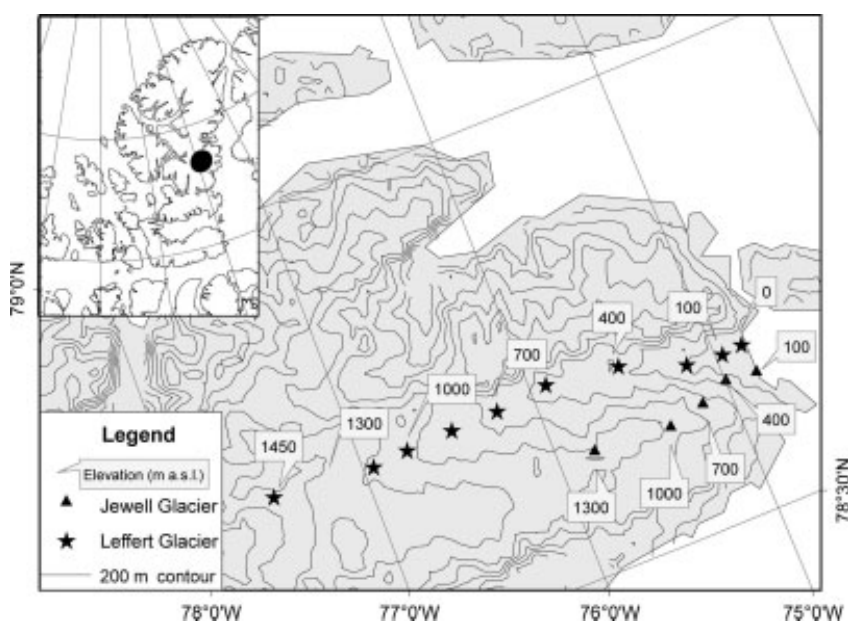

Fig. 1. Map showing sample site locations on Leffert and Jewell Glaciers, POW Icefield, Ellesmere Island.

(Koerner, 1979). The North Water polynya lies adjacent to POW in northern Baffin Bay, nestled between Greenland and Ellesmere Island (Dunbar and Dunbar, 1972; Steffen, 1985). The extent of the North Water varies seasonally and interannually, with near-complete ice cover in early January and an area of open water increasing south of the Nares Strait ice bridge throughout the winter and spring (Barber and others, 2001). In most years, the North Water is the only significant source of 'local' moisture for the POW Icefield from winter to mid-spring (January-May).

High-resolution snow-pit samples were collected between 21 April and 10 June 2004 for isotopic and chemical analyses of fall 2003 to spring 2004 accumulation. Two transects in northeast POW (Fig. 1) were sampled in order to examine the relative influence of elevation vs distance inland on the transport and deposition of DMS oxidation products. Lower Leffert Glacier, with a low slope angle $\left(\sim 2.3^{\circ}\right)$, was sampled every $150 \mathrm{~m}$ in elevation between sea level and $1450 \mathrm{~m}$ a.s.l. The adjacent steeper-gradient Jewell Glacier was sampled every $300 \mathrm{~m}$ in elevation from 100 to $1300 \mathrm{~m}$ a.s.l. At each site, two sample suites were collected for each $10 \mathrm{~cm}$ depth interval. A $100 \mathrm{~mL}$ polyethylene bottle (dried, pre-cleaned five times with distilled deionized $(18.2 \mathrm{M} \Omega)$ water) was filled with snow for ion-chemistry and water-isotope analysis. The second suite, collected in dried pre-cleaned $500 \mathrm{~mL}$ polyethylene bottles, and concentrated for sulphate isotope analysis, was also analyzed for ion concentration. Six litres water equivalent of each $10 \mathrm{~cm}$ snow stratum were collected, melted and evaporated by boiling to $\leq 0.5 \mathrm{~L}$. Stainless-steel pots, on propane-fueled stoves, sheltered in nylon tents, were used to melt and evaporate samples. Each sample took 4-5 hours to process. Distilled deionized water transported to POW from the University of Calgary stable-isotope laboratory was processed as a field blank. Sample bottles were sealed with Parafilm. Small-volume samples were kept frozen until analyzed. Large-volume samples were refrozen in the field, and then refrigerated until processed for analysis.

\section{ANALYSIS}

Snow samples for sulphate isotope analysis were processed in class 100 clean-room conditions in the University of Calgary stable-isotope laboratory, and prepared for analysis as barium sulphate precipitated from concentrated snowmelt. Glassware used in the processing was soaked in $1 \%$ nitric acid for a minimum of 1 week and washed five times with distilled deionized water $(18.2 \mathrm{M} \Omega)$. Ion concentration values were based on the low-volume sample suite. $\delta^{34} \mathrm{~S}$ values and discussion for the apportionment were based on the high-volume sample suite. The small-volume sample suite was kept frozen until the day before analysis, typically 3 months for ion chromatography (IC) and 13-16 months for inductively coupled plasma mass spectrometry (ICP-MS) analysis. The large-volume samples were refrigerated, 4-14 months at $4{ }^{\circ} \mathrm{C}$ prior to preparation for sulphate isotopic analysis, 3-7 months for IC analysis and 16 months for ICPMS analysis. Previous analyses have shown no change in the sulphate isotope composition for samples stored in this manner.

The $\delta^{34} \mathrm{~S}$ of the barium sulphate was analyzed on a Prism isotope ratio mass spectrometer in continuous flow mode (CF-EA-IRMS). Standards with isotope compositions bracketing those of the samples were used as reference to calibrate to the international standard V-CDT. An average standard deviation of $\pm 0.19 \%$ o was determined from multiple (three to seven) analyses. Long-term monitoring of the international standard NBS 127 run each day gives a value of $+21.13 \%$ o $\pm .22 \%$.

Melted snow samples were filtered prior to ion-concentration quantification using Acrodisc $0.2 \mu \mathrm{m}$ Supor (PES) membrane filters. Anion concentration was quantified using a Dionex ICS-2500 IC with a $4 \mathrm{~mm}$ AS18 column, and $\mathrm{KOH}$ eluent (0-4.5 min: $22 \mathrm{mM}$; 4.5-13.1 min: $40 \mathrm{mM}$; 13.2-18 min: $22 \mathrm{mM}$ ). A six-point calibration using 10 , 100, 500, 1000, 2000 and 10000 dilution of standards gave a sulphate calibration range of 15-15000 ppb. The detection limit for sulphate was $1 \mathrm{ppb}$. Deionized water, a duplicate sample and a standard were run after every ten samples. High-concentration samples were diluted to bring ion concentration into the standard range. Standard error for 28 duplicate samples was $1.5 \mathrm{ppb}$.

Cation concentration was quantified using internal standard methodology on a Perkin Elmer Elan 6000 ICP-MS using dual detector mode with a blank subtraction after internal standard correction. A four-point calibration curve $(0,0.025$, $0.050,0.100 \mathrm{ppm}$ for $\mathrm{Na}$ ) was used. To each $4.9 \mathrm{~mL}$ sample, $0.05 \mathrm{~mL}$ each of C-star $\mathrm{HNO}_{3}$ and an internal sample containing $100 \mathrm{ppb}$ of $\mathrm{Bi}, \mathrm{Sc}$ and In was added. High-ionconcentration samples were diluted as needed to bring ion concentrations into the calibrated region. An injection volume of approximately $2.5 \mathrm{~mL}$ was analyzed using a flow rate of $1 \mathrm{~mL} \mathrm{~min}^{-1}$. The runs used 35 sweeps per reading, one reading per replicate and three replicates. Sodium dwell time was $10 \mathrm{~ms}$, and integration time was $350 \mathrm{~ms}$. Final results are the average of three replicates. The detection limit for sodium was $1 \mathrm{ppb}$, with relative standard deviation from ten duplicates of $0.63 \%$ at $5 \mathrm{ppb}$ and $3.49 \%$ at $100 \mathrm{ppb}$. The average standard error for six duplicate samples from 200 to $800 \mathrm{ppb}$ was 3.7, and for four duplicate samples in the 1400-6200 ppb range it was 36 .

\section{RESULTS}

\section{Field blanks}

Sulphate concentrations from four field blanks processed under different conditions were $5-59 \mathrm{ppb}$, with an average of $30 \mathrm{ppb} . \delta^{34} \mathrm{~S}$ values for two field blanks from two field 

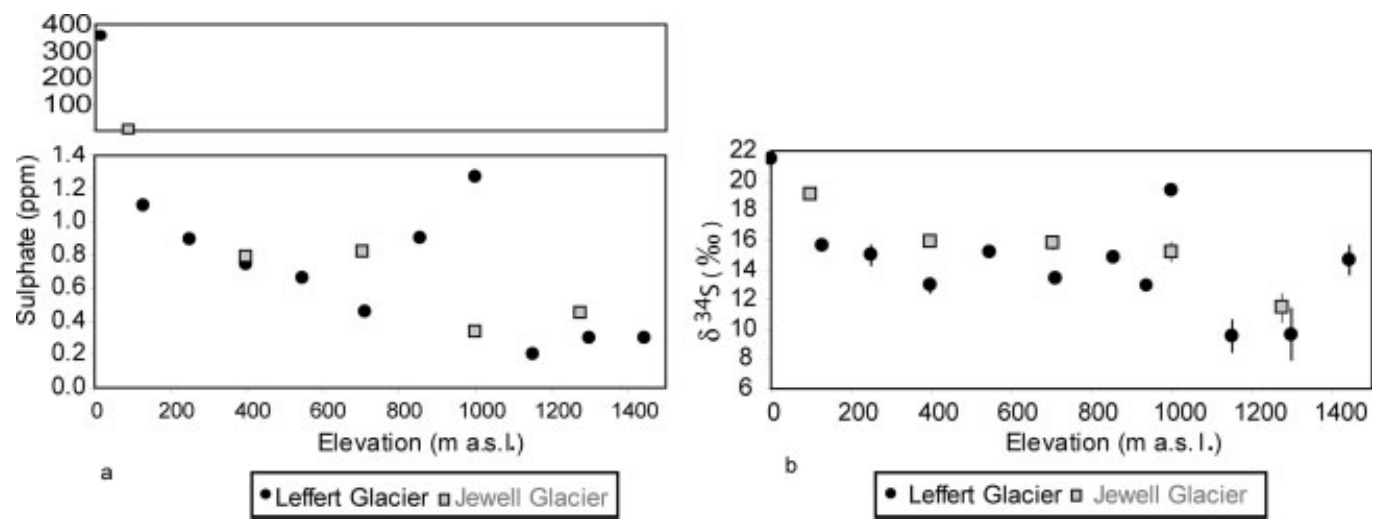

Fig. 2. Sulphate concentrations (a) and $\delta^{34} \mathrm{~S}$ (b) of surface snow samples on Leffert and Jewell Glaciers as a function of elevation. Note that two scales are used in (a).

seasons were $+21.7 \%$ and $+26.5 \%$, respectively. As fieldblank-corrected $\delta^{34} \mathrm{~S}$ values will be influenced by the values chosen, average values in results presented below have been plotted with bars indicating maximum and minimum values based on these field-blank isotope and concentration values.

\section{Laboratory blanks}

Ion concentrations of the distilled deionized (18.2 M $\Omega$ ) water used in the laboratory were below the detection limit (1 ppb for sulphate) for all major ions with the exception of $\mathrm{Cl}^{-}$. During laboratory preparation for sulphate isotopic analysis, samples were exposed to the class 100 clean laboratory atmosphere for 36-72 hours. Laboratory blanks, $500 \mathrm{~mL}$ of distilled deionized water processed with sample sets and evaporated to $10 \mathrm{~mL}$, had sulphate concentrations from 0 to $19 \mathrm{ppb}$ and an average of $6 \mathrm{ppb}$. No $\delta^{34} \mathrm{~S}$ values are available for background atmospheric sulphate in the laboratory, so a correction for this has not been made.

\section{Surface snow}

Ion-chemistry and sulphur-isotope values for 11 surface snow samples from the Leffert Glacier transect and 5 from the Jewell Glacier transect are presented. The Jewell Glacier transect shows a general decrease in concentration of $\mathrm{Cl}^{-}$, $\mathrm{SO}_{4}{ }^{2-}, \mathrm{Ca}^{2+}, \mathrm{Na}^{+}, \mathrm{Mg}^{2+}$ and $\mathrm{K}^{+}$from low elevations to higher elevations and with increased distance inland (Fig. 2a; other ions not shown). Concentration trends on Leffert Glacier are more complex. There is a decrease in concentration of $\mathrm{Cl}^{-}, \mathrm{SO}_{4}{ }^{2-}, \mathrm{Ca}^{2+}, \mathrm{Na}^{+}, \mathrm{Mg}^{2+}$ and $\mathrm{K}^{+}$from sea level to $550 \mathrm{ma}$ a.s.l., similar to what is seen on Jewell Glacier. Above this altitude, ion concentrations increase from 700 to 1000 ma.s.l., followed by a large decrease in concentration for the sites from 1150 to 1450 ma.s.I. Ion concentrations at $1000 \mathrm{ma.s.l}$. typically exceed concentrations at $100 \mathrm{~m}$ a.s.l. Surface spring snow at sea level had a sulphate concentration of 362 ppm. Similar snow on Jewell and Leffert Glaciers had sulfate concentrations ranging from 0.2 to $4.5 \mathrm{ppm}$ (204-4580 ppb), peaking at $100 \mathrm{~m}$ a.s.I. on Jewell Glacier and 1000 ma.s.I. on Leffert Glacier. MSA ranged from 0 to $8 \mathrm{ppb}$, increasing with elevation on Jewell Glacier, but this trend is absent on Leffert Glacier. Nitrate concentrations show a general decrease with elevation increase. $\delta^{34} \mathrm{~S}$ values for surface snow range from $+9.9 \%$ to $+21.4 \%$ (Fig. 2b) and show a trend that is weaker than but similar to that of sulphate concentration.

\section{Depth profiles from five locations}

Depth profiles for the five sites where complete datasets were available while this paper was in preparation are shown in Figure 3. Fall 2003 to spring 2004 snow accumulation was $30-90 \mathrm{~cm}$. All sites were below the ablation zone, with glacial ice defining snow-pit base. Sulphate concentration ranged from 16 to $126 \mathrm{ppb}$ at the base of the snowpack, and 204 to 742 ppb at the surface. In all profiles, minimum concentrations at depth increased to higher concentrations at the surface. This trend is more pronounced at lower elevations (Fig. 3a), where sulphate concentrations are also higher. $\delta^{34} \mathrm{~S}$ values show an opposite trend, with more positive values generally observed at depth. Surface $\delta^{34} \mathrm{~S}$ values are +9.5 to $+15.2 \%$, increasing with depth to +16.4 to $+20.9 \%$ at the base of the snowpack. This pattern is clearest in the lower-elevation profiles (Fig. 3c) from Leffert Glacier. A similar trend is possibly seen at $1150 \mathrm{~m}$ a.s.l. on Leffert Glacier, but is not apparent at $1000 \mathrm{~m}$ a.s.I. on Jewell Glacier (Fig. 3d). However, these higher-elevation sites show interesting similarities in pattern with depth.

\section{DISCUSSION}

\section{Surface snow transects}

Surface snow samples from the Jewell Glacier transect can be interpreted as decreasing marine aerosol impact with greater vertical and horizontal distance from sea-water sources. Similar trends are well documented in the literature (e.g. Mayewski and others, 1987; Fischer and others, 1998; Sharp and others, 2002). Lower $\delta^{34} S$ values at higher elevation and greater distance inland reinforce this interpretation. The general trend in surface snow of Jewell Glacier is also seen on Leffert Glacier, with additional complexities. The main transport route for marine aerosols is up Leffert Glacier from east to west and can explain the similarity in pattern on the two glaciers. In addition, on Leffert Glacier a marked increase in ion concentration from 700 to $1000 \mathrm{~m}$ a.s.l., peaking at $1000 \mathrm{~m}$ a.s.l., is mimicked by $\delta^{34} \mathrm{~S}$ values. These higher values suggest that an additional aerosol source could be affecting the 850-1150 m a.s.l. sites of Leffert Glacier. There are two plausible scenarios: additional marine aerosols (possibly from Flagler Bay Polynya (Schledermann, 1996)) or a lithic source. Topographic features suggest dominant airflow to the glaciers from the southeast. However, a small unnamed fjord north of 

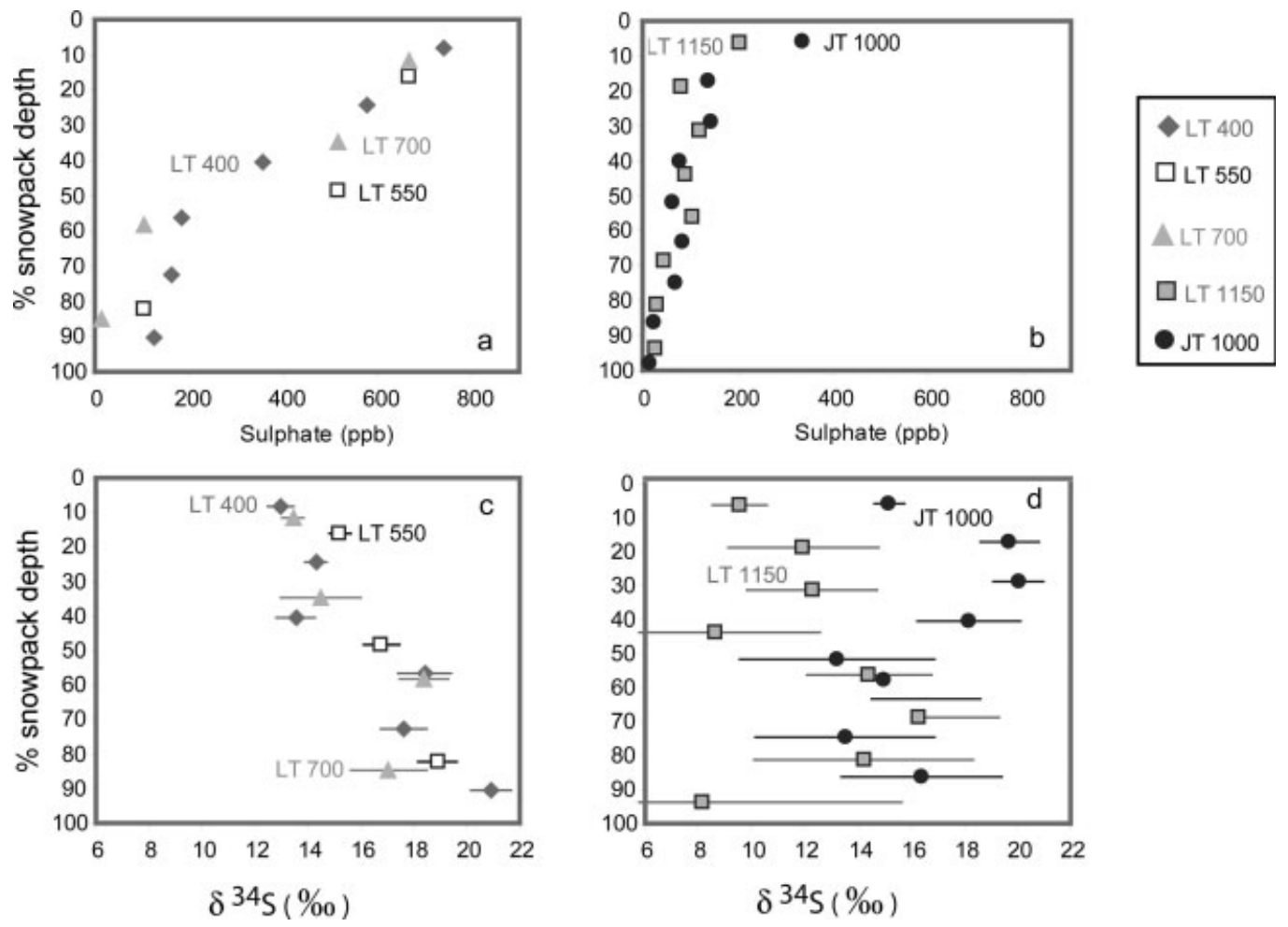

Fig. 3. Sulphate concentration $(\mathrm{a}, \mathrm{b})$ and $\delta^{34} \mathrm{~S}(\mathrm{c}, \mathrm{d})$ as a function of snowpack depth at five sampling locations. Note: average $\delta^{34} \mathrm{~S}$ values are plotted with minimum and maximum field-blank-corrected $\delta^{34} S$ values indicated with bars.

this region, opening to the northeast, may form a more direct transport route for marine aerosols than is typical for the remainder of Leffert Glacier. It is also possible that this fjord may also be a pathway for lithogenic aerosol transport from subaerial regions north and west of the POW Icefield.

\section{Depth profiles at five locations}

Trends in the POW depth profiles can be understood in the context of seasonal cycles of Arctic anthropogenic, sea-salt and biogenic sulphate aerosols. The deepest layers represent the previous year's fall snow, when aerosol levels in the atmosphere are low (based on $\delta^{18} \mathrm{O}$ of snow; data not shown). The very positive $\delta^{34} \mathrm{~S}$ values at depth likely reflect greater marine contributions in early fall before the seasonal

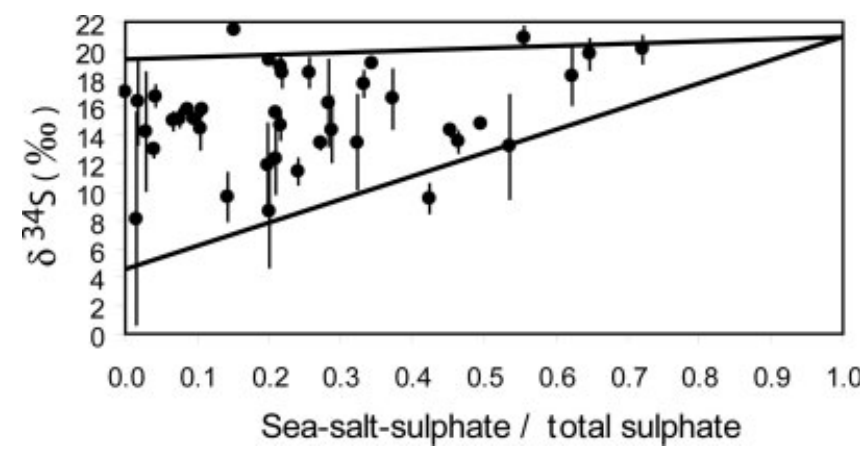

Fig. 4. $\delta^{34} \mathrm{~S}$ values vs the ratio of sea-salt sulphate to total sulphate. On this plot, samples with no sea-salt sulphate would be bounded by a lower limit of $\delta^{34} S_{A}=+4.3 \%$ and an upper limit of $\delta^{34} S_{\text {DMS }}=+19.5 \%$. Samples with $100 \%$ sea-salt sulphate would have a $\delta^{34} S_{S S}=+21 \%$. The mixing of sea water with a $\delta^{34} S_{A}$ source would form the lower line on the plot, and the mixing of sea water with a $\delta^{34} S_{\mathrm{DMS}}$ source would form the upper line. sea ice forms in Baffin Bay and sea-ice leads are frozen over. As winter progresses, more anthropogenic sulphate accumulates in the atmosphere and is likely deposited in maximum concentration in April-May snowfall (Sirois and Barrie, 1999; Sharp and others, 2002).

\section{Non-sea-salt sulphate}

Non-sea-salt sulphate was calculated assuming a 100\% seasalt sodium source, using a sea-water sulphate to sodium mass ratio of 0.252 (e.g. Murray, 2000). $\delta^{34} S_{\text {nss }}$ (non-sea-salt sulphate) was calculated using a sea-salt sulphate value of $\delta^{34} \mathrm{~S}_{\mathrm{ss}}=+21 \%$. $\quad \delta^{34} \mathrm{~S}_{\text {Total }}$ values vs the ratio of sea-salt sulphate to total sulphate are plotted in Figure 4. On this plot, samples with no sea-salt sulphate would be bounded by a lower limit of $\delta^{34} \mathrm{~S}_{\mathrm{A}}=+4.3 \%$ and an upper limit of $\delta^{34} S_{\text {DMS }}=+19.5 \%$. Samples with $100 \%$ sea-salt sulphate would have a $\delta^{34} S_{S S}=+21 \%$. The mixing of sea water with a $\delta^{34} S_{A}$ source forms the lower line on the plot, and the mixing of sea water with a $\delta^{34} S_{\text {DMS }}$ source forms the upper line. Figure 4 shows that $\delta^{34} \mathrm{~S}$ values used to apportion the three major sulphate sources to POW snowpack are reasonable for most data, with only two points falling outside the expected range.

\section{Apportionment of non-sea-salt sulphate}

Assuming no fractionation occurs on oxidation of DMS, non-sea-salt sulphate of surface snow samples was apportioned into anthropogenic sulphate (which includes volcanic degassing) using a value of $\delta^{34} \mathrm{~S}_{\mathrm{A}}=+4.3 \%$, and ocean biogenic sulphate using $\delta^{34} \mathrm{~S}_{\mathrm{DMS}}=+19.5 \%$. Total sulphate $\left(\mathrm{S}_{\text {Total }}\right)$, sea-salt sulphate $\left(\mathrm{S}_{\mathrm{SS}}\right)$, anthropogenic sulphate $\left(\mathrm{S}_{\mathrm{A}}\right)$ and ocean biogenic sulphate $\left(\mathrm{S}_{\mathrm{DMS}}\right)$ for spring surface samples from the Leffert transect are shown in Figure $5 \mathrm{a}$, and from the Jewell transect in Figure 5b. Sulphate source 

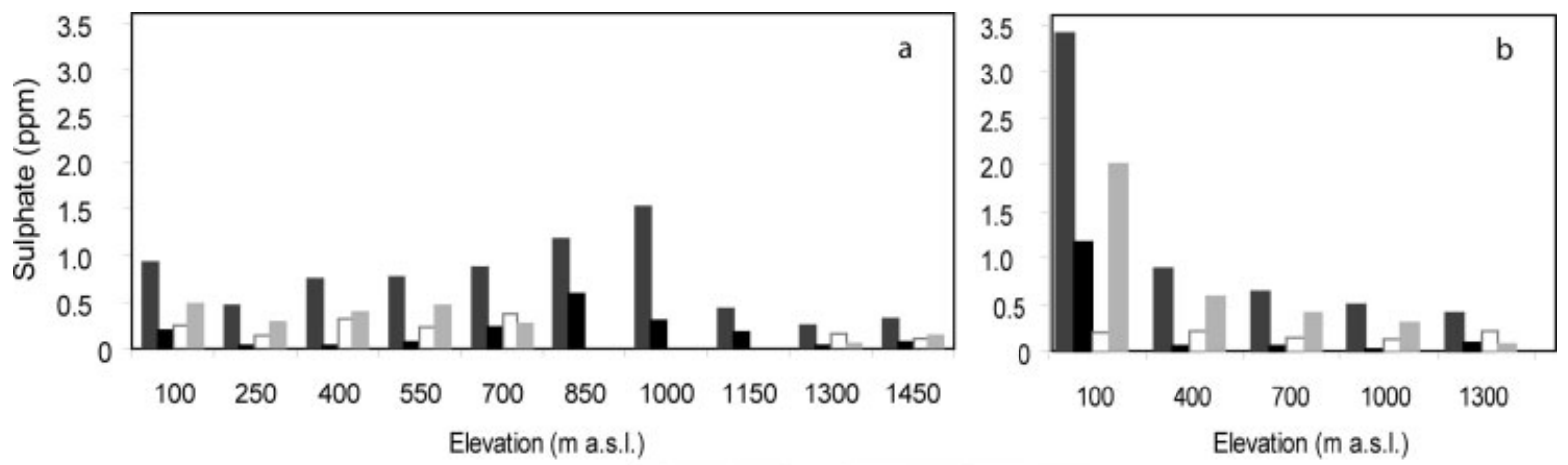

Total $\mathbf{\square}$ Sea Salt $\square$ Anthropogenic $\mathbf{D M S}$

Fig. 5. Apportionment estimates of major sulphate sources for surface samples on Leffert Glacier (a) and Jewell Glacier (b). DMS and anthropogenic components were not calculated for the $850-1150 \mathrm{~m}$ a.s.l. sites due to the possibility of an additional sulphate source in this region.

was not apportioned for the $850-1150 \mathrm{~m}$ a.s.I. sites, as there may be an additional sulphate source affecting this section of Leffert Glacier (as discussed above). Otherwise, two distinct sulphate concentration patterns are apparent. On Jewell Glacier, total sulphate and marine biogenic sulphate decline with increased elevation and distance inland at a reasonable approximation of exponential decrease. Sea-salt sulphate also declines, while anthropogenic contributions remain relatively constant. This is interpreted as the biogenic sulphate originating from regional open water at the surface, whereas anthropogenic sulphate from long-range transport is ubiquitous at all levels.

\section{CONCLUSIONS}

Preliminary ion chemistry and sulphur isotope values for surface snow samples from two transects, and five depth profiles on POW, show distinct seasonal trends and spatial patterns. We believe that this study is the first to quantify $\delta^{34} S$ seasonal variations in polar snow. Ion concentrations and $\delta^{34} \mathrm{~S}$ values in surface snow along two transects are interpreted as indicating decreasing marine aerosol impact with greater vertical and horizontal distance from sea-water sources. This trend is clearest on Jewell Glacier, where decreasing $\mathrm{SO}_{4}{ }^{2-}$ and $\mathrm{Na}^{+}$concentrations (along with $\mathrm{Cl}^{-}$, $\mathrm{Mg}^{2+}$ and $\mathrm{K}^{+}$) in surface snow samples are mimicked by decreasing $\delta^{34} \mathrm{~S}$ values. Surface snow of Leffert Glacier shows a more complex pattern of decreased ion concentrations and $\delta^{34} \mathrm{~S}$ values with inland distance and elevation increase, combined with a marked increase in concentration and $\delta^{34} S$ value in the $700-1000 \mathrm{ma}$ a.s.l. section. The increased values in this section are interpreted as reflecting an additional (lithic and/or marine) aerosol source.

Both total sulphate and non-sea-salt sulphate show increased concentrations from fall to spring accumulation in depth profile. $\delta^{34} \mathrm{~S}$ values have an opposite trend, with heavier values generally observed in the basal fall snowpack. The pattern is clearest for the low-elevation sites. These profiles are consistent with mainly marine contributions in early fall, giving low sulphate concentrations and high $\delta^{34} \mathrm{~S}$ values, with increasing amounts of anthropogenic sulphate in late-winter and spring snow which increases ion concentration and decreases $\delta^{34} S$ values.

Two distinct sulphate concentration patterns are apparent from the apportionment of non-sea-salt sulphate into anthropogenic and marine biogenic components. An exponential decrease is approximated in the total sulphate and marine biogenic sulphate of the steeper-sloped Jewell Glacier as elevation and inland distance increase. Sea-salt sulphate also declines, while anthropogenic contributions remain relatively constant. These patterns of proximal marine influence in the surface snow of Jewell Glacier are much less clear on the gently sloped Leffert Glacier. The increased total and sea-salt sulphate concentrations in the mid-section of the transect overwhelm the distance and elevation trend. The anthropogenic component of surface snow remains relatively constant over the two transects, signifying a vertically well-mixed source. DMS sulphate clearly is associated with low elevation, and the exponential decrease with altitude implies a dominant regional surface source of DMS sulphate on the ice fields. The North Water Polynya in Baffin Bay and, to a smaller extent, other polynyas and leads in the region are likely the major source of DMS on the icepack rather than DMS or DMS sulphate that has undergone long-range transport from the North Atlantic. These results suggest that DMS sulphate may well be able to provide a reasonable indication of open-water conditions in Baffin Bay and Nair Strait and warrants further study using isotope apportionment techniques with sulphate in ice cores.

\section{ACKNOWLEDGEMENTS}

We thank the following people for assistance on this project: M. Wieser, S. Taylor and N. Lozano from the Isotope Science Laboratory at the University of Calgary, and M. Sharp and G. Chen at the University of Alberta. Special thanks to A. Taylor for his competent and congenial field assistance/ guiding. We also thank the Natural Sciences and Engineering Research Council, Canada, the Canadian Foundation for Climate and Atmospheric Sciences, the Northern Scientific Training Program and the Polar Continental Shelf Project for financially supporting this project. In addition, we thank the anonymous reviewers whose critical feedback greatly strengthened this paper.

\section{REFERENCES}

Alexander, B., J. Savarino, N.I. Barkov, R.J. Delmas and M.H. Thiemens. 2002. Climate driven changes in the oxidation pathways of atmospheric sulfur. Geophys. Res. Lett., 29(14), 1685. (10.1029/2002GL014879.) 
Alexander, B., M.H. Thiemens, J. Farquhar, A.J. Kaufman, J. Savarino and R.J. Delmas. 2003. East Antarctic ice core sulfur isotope measurements over a complete glacial-interglacial cycle. J. Geophys. Res., 108(D24), 4786. (10.1029/ 2003JD003513.)

Alexander, B., J. Savarino, K.J. Kreutz and M.H. Thiemens. 2004. Impact of preindustrial biomass-burning emissions on the oxidation pathways of tropospheric sulfur and nitrogen. J. Geophys. Res., 109(D8), D08303. (10.1029/2003JD004218.)

Andreae, M.O. 1990. Ocean-atmosphere interactions in the global biogeochemical sulfur cycle. Mar. Chem., 30, 1-29.

Barber, D.G., J.M. Hanesiak, W. Chan and J. Piwowar. 2001. Seaice and meteorological conditions in northern Baffin Bay and the North Water polynya between 1979 and 1996. Atmos.Ocean, 39(3), 343-359.

Calhoun, J., T.S. Bates and R.J. Charlson. 1991. Sulfur isotope measurements of submicron sulfate aerosol particles over the Pacific Ocean. Geophys. Res. Lett., 18(10), 1881-1884.

Charlson, R.J., J.E. Lovelock, M.O. Andreae and S.G. Warren. 1987. Oceanic phytoplankton, atmospheric sulphur, cloud albedo and climate. Nature, 326(6114), 655-661.

Dunbar, M. and M.J. Dunbar. 1972. The history of the North Water. Proc. R. Soc. Edinb., Ser. B, 72, 231-241.

Fischer, H., D. Wagenbach and J. Kipfstuhl. 1998. Sulfate and nitrate firn concentrations on the Greenland ice sheet. 1. Largescale geographical deposition changes. J. Geophys. Res., 103(D17), 21,927-21,934.

Grootes, P.M., M. Stuiver, J.W.C. White, S. Johnsen and J. Jouzel. 1993. Comparison of oxygen isotope records from the GISP2 and GRIP Greenland ice cores. Nature, 366(6455), 552-554.

Houghton, J.T. and 7 others. 2001. Climate change 2001: the scientific basis. Contribution of Working Group I to the Third Assessment Report of the Intergovernmental Panel on Climate Change. Cambridge, etc., Cambridge University Press.

Jonsell, U., M.E. Hansson, C.-M. Morth and P. Torssander. 2005. Sulfur isotopic signals in two shallow ice cores from Dronning Maud Land, Antarctica. Tellus, 57B(4), 341-350.

Koerner, R.M. 1979. Accumulation, ablation, and oxygen isotope variations on the Queen Elizabeth Islands ice caps, Canada. J. Glaciol., 22(86), 25-41.

Koerner, R.M. and D.A. Fisher. 1990. A record of Holocene summer climate from a Canadian high-Arctic ice core. Nature, 343(6259), 630-631.

Legrand, M. 1995. Sulphur-derived species in polar ice: a review. In Delmas, R.J., ed. Ice core studies of global biogeochemical cycles. Berlin, etc., Springer-Verlag, 91-119. (NATO ASI Series I: Global Environmental Change 30.)

Legrand, M. 1997. Ice-core records of atmospheric sulfur. Philos. Trans. R. Soc., Ser. B, 352(1350), 241-250.

Li, S.-M., L.A. Barrie and A. Sirois. 1993. Biogenic sulfur aerosol in the arctic troposphere: 2. Trends and seasonal variations. J. Geophys. Res., 98(D11), 20,623-20,632.

McArdle, N., P. Liss and P. Dennis. 1998. An isotopic study of atmospheric sulphur at three sites in Wales and at Mace Head, Eire. J. Geophys. Res., 103(D23), 31,079-31,094.

Mayewski, P.A., M.J. Spencer, W.B. Lyons and M. Twickler. 1987. Seasonal and spatial trends in South Greenland snow chemistry. Atmos. Environ., 21(4), 863-869.

Murray, J.W. 2000. The oceans. In Jacobson, M., R. Charlson, H. Rodhe and G. Orians, eds. Earth system science: from biogeochemical cycles to global changes. London and San Diego, CA, Academic Press, 256-257.

Newman, L., H.R. Krouse and V.A. Grinenko. 1991. Sulphur isotope variation in the atmosphere. In Krouse, H.R. and
V.A. Grinenko, eds. Stable isotopes: natural and anthropogenic sulphur in the environment. Chichester, etc., John Wiley \& Sons, 133-176.

Nielsen, H. and 6 others. 1991. Lithospheric sources of sulphur. In Krouse, H.R. and V.A. Grinenko, eds. Stable isotopes: natural and anthropogenic sulphur in the environment. Chichester, John Wiley \& Sons, 65-132.

Norman, A.L. and 6 others. 1999. Sources of aerosol sulphate at Alert: apportionment using stable isotopes. J. Geophys. Res., 104(D9), 11,619-11,631.

Norman, A.L., W. Belzer and L. Barrie. 2004. Insights into the biogenic contribution to total sulphate in aerosol and precipitation in the Fraser Valley afforded by isotopes of sulphur and oxygen. J. Geophys. Res., 109(D5), D05311. (10.1029/ 2002JD003072.)

North Greenland Ice Core Project (NorthGRIP) members. 2004. High-resolution record of Northern Hemisphere climate extending into the last interglacial period. Nature, 431(7005), $147-151$.

Nriagu, J.O., R.D. Coker and L.A. Barrie. 1991. Origin of sulphur in Canadian Arctic haze from isotope measurements. Nature 349(6305), 142-145.

Patris, N., J. Jouzel and R.J. Delmas. 2000. Isotopic signatures of sulfur in shallow Antarctic ice core. J. Geophys. Res., 105(D6), 7071-7078.

Patris, N. and 6 others. 2002. First sulfur isotope measurements in central Greenland ice cores along the preindustrial and industrial periods. J. Geophys. Res., 107(D11), 6-13.

Rigor, I.G. and J.M. Wallace. 2004. Variations in the age of Arctic sea-ice and summer sea-ice extent. Geophys. Res. Lett., 31(9), L09401. (10.1029/2004GL019492.)

Saltzman, E.S., G.W. Brass and D.A. Price. 1983. The mechanism of sulfate aerosol formation: chemical and sulfur isotopic evidence. Geophys. Res. Lett., 10(7), 513-516.

Savarino, J., S. Bekki, J. Cole-Dai and M.H. Thiemens. 2003a. Evidence from sulfate mass independent oxygen isotopic compositions of dramatic changes in atmospheric oxidation following massive volcanic eruptions. J. Geophys. Res., 108(D21), 4671. (10.1029/2003JD003737.)

Savarino, J., A. Romero, J. Cole-Dai, S. Bekki and M.H. Thiemens. 2003b. UV induced mass-independent sulfur isotope fractionation in stratospheric volcanic sulfate. Geophys. Res. Lett., 30(21), 2131. (10.1029/2003GL018134.)

Schledermann, P. 1996. Voices in stone: a personal journey into the Arctic past. Calgary, Arctic Institute of North America of the University of Calgary.

Sharma, S., D. Lavoué, H. Cachier, L.A. Barrie and S.L. Gong. 2004. Long-term trends of the black carbon concentrations in the Canadian Arctic. J. Geophys. Res., 109(D15), D15203. (10.1029/2003JD004331.)

Sharp, M., M. Skidmore and P. Nienow. 2002. Seasonal and spatial variations in the chemistry of a High Arctic supraglacial snow cover. J. Glaciol., 48(160), 149-158.

Sirois, A. and L.A. Barrie. 1999. Arctic low tropospheric aerosol trends and composition at Alert, Canada, 1980-1995. J. Geophys. Res., 104(D9), 11,599-11,618.

Steffen, K. 1985. Warm water cells in the North Water, northern Baffin Bay during winter. J. Geophys. Res., 90(C5), 9129-9136.

Toom-Sauntry, D. and L.A. Barrie. 2002. Chemical composition of snowfall in the high Arctic: 1990-1994. Atmos. Environ., 36(15-16), 2683-2693.

von Glasow, R. and P.J. Crutzen. 2004. Model study of multiphase DMS oxidation with a focus on halogens. Atmos. Chem. Phys., 4, 589-608. 